\title{
“全程分段融入式” 创新创业教育体系的构建与实践
}

潘越 刘亚妮 吴泽宇 陈雨

重庆房地产职业学院

DOI:10.32629/er.v2i11.2196

[摘 要] 党中央、国务院作出了加快实施创新驱动发展战略、建设创新型国家的重大决策,在高等学校开展创新创业教育,是教育系统服务于 创新型国家建设的重大战略举措。重庆房地产职业学院认真分析了职业院校创新创业教育观念滞后, 创新创业教育与专业教育脱节等问题, 以培 养学生综合素质为目标,对构建创新创业教育体系进行了全面的探索与实践,形成了具有特色的 “全程分段融入式” 创新创业教育体系。

[关键词] 创新创业; 教育体系; 构建

\section{1 概述}

随着我国经济社会发展进入新常态, 党中央、国务院作出了加快实施 创新驱动发展战略、建设创新型国家的重大决策。但以就业教育为特征的 高职教育, 其创新创业教育依然停留在缺乏系统系、目标性, 仅作为专业教 育的辅助工作阶段。

重庆房地产职业学院认真分析了职业院校创新创业教育观念滞后, 创新创业教育与专业教育脱节等问题, 以培养学生综合素质为目标, 全 面提升学生创新创业能力, 并与本地企业和政府部门共同协作, 构建全 程分段融入式创新创业教育体系, 探索创新创业教育与思政教育相结合 的有效途径。

\section{2 建设的内容}

2. 1建设 “全程分段融入式” 创新创业教育体系

以创新创业教育流程为依托, 将创新创业分为创新创业思维与方法培 养、创新创业模拟项目实训、创新创业实践项目孵化三个阶段, 同时构建 创新创业课程群, 结合专业教育体系, 以创新创业课程实训、创业实践、创 新创业服务三大平台为支撑, 将创新创业教育融合于专业教育全过程, 形 成全程分段融入式创新创业教育体系。

\section{全程分段融入式创新创业教育体系}

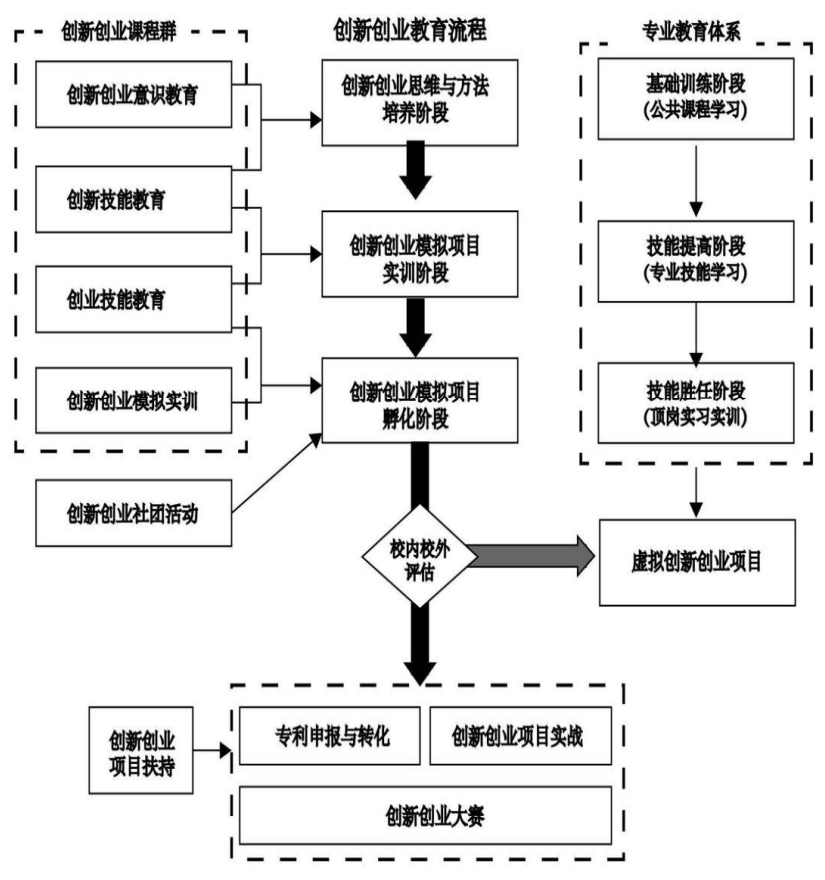

2. 2探索专业教育中融入创新创业项目与方法

结合分段递进式的专业教育人才培养模式, 将创新创业思维与方法融 入到专业教育的课程体系中, 并将创新创业项目转化为专业课程内容, 确 保创新创业项目的转化与实现。同时结合专业特色形成不同类别的创新创 业项目, 如营销类专业结合 “互联网+”创新思维形成 “互联网+”创业项 目, 建筑类专业结合装配式建筑形成建筑类新技术专利创新, 艺术类专 业结合设计创新思维形成设计创意和外观新型专利创新。并且结合校内 校外专家评审, 对创业项目进行评估, 对于有市场价值和可行性创业项 目, 在顶岗实习阶段进行校内外企业双向扶持, 实现由创业计划到开办 企业的过渡。

2. 3构建 “校政企园” 共建创新创业教育支撑平台

学院构建创新创业课程群, 并制定负责课程标准制定及具体实施; 重 庆市人力资源开发培训中心与重庆市大学生就业创业公共服务中心负责 提供创新创业案例、创业导师团队建设、项目立项论证及服务、学生就业 指导、人才测评、联合创业等; 科技创新型企业及众创空间负责配备创业 导师入站、提供 “创业见习” 实践基地, 并帮助项目孵化。形成 “校政企 园”多方联动、优势互补的创新创业支撑平台。

\section{3 建设成果的应用及推广}

3.1四方联动优势助推学生就业竞争力提升

3. 1. 1 教学组织模式保障创新创业教育面向全体学生

按照行业需要的高素质技能型人才的要求, 将创新创业教育贯通全过 程, 全面实施创新创业培养。各专业的课程体系中涵盖创新创业板块, 依托 “众创梦工场” 和 “大学生创业捊化园” 的创新创业课程实训、创业实践、 创新创业服务三大平台, 使专业教育与创新创业教育有机结合。创新课程 体, 以专业课实践教学与创新创业训练有机结合为重点, 以学生综合素质 教育、技能竞赛和双证融通为补充的创新创业教育立体课程体系。将创新 创业教育纳入学分管理, 学生在校学习期间的发明专利、专业竞赛获奖以 及各种创业实践活动均可认定为创新创业学分。创新创业教育获得重庆市 民办教育创新创业教育课程奖。

3.1.2创业模拟实训学生普遍受益

重庆市人力资源开发培训中心作为政府部门, 帮助学院筹建创新创业 项目资源库, 培训创业项目教育师资, 帮助 4100 人完成创业模拟实训学习; 与重庆市大学生就业创业公共服务中心协同, 联合开展创新创业导师团队 建设、项目立项论证及服务、学生就业指导、人才测评、联合创业等活动, 测评中心累计为申请自主创业的学生测评千余人; 协助学院完成校内创业 模拟实训基地设计与项目论证。

3. 1.3 合作企业助力师资水平提升

学院众创空间作为创新创业孵化基地, 不仅负责配备创业导师、安 
排创业实习, 还接纳创新创业专职教师挂职锻炼。目前, 学校已有校企创 新创业导师 98 人, 有育创机器人、私享家、电供暖、客立方、杰算盘科 技、胖娃儿创意等创业导师团队 20 余个。众创空间担负了学院创新创业 实践、项目孵化和创新项目转化, 并成为创新创业专职教师挂职锻炼的 实战基地。

\section{1.4 创新创业竞赛取得丰硕成果}

学院积极组织创新创业竞赛活动, 各系纷纷组织各类型创业竞赛, 如 “互联网+创新创业大赛”、广告设计类等, 参赛项目累计 2095余项, 参与学 生人数达 4801 人, 各类获奖 329 项, 让我校创新创业活动达到了一个新的高 点。获得第二届中国 “互联网+” 大学生创新创业大赛优秀组织单位。

3.2 师生创新专利引领专业提升

在专业教学中, 按照不同专业所对应的行业和职业特点, 在专业课程 中融入了创新创业项目和方法, 激发了学生的创新创业兴趣。在学校的高 度重视和科学指导下, 学生的创新创业项目从2015年的 18 个增加到 25 个。 学校师生发表教研教改论文67篇 (其中 23 篇为创新创业教育类论文), 承担 市级以上教改项目 23 项 (其中7项与创新创业教育相关), 承担纵横向课题 17项、经费150余万, 获得国家专利授权69项, 学生研发专利110项, 其中69 项已获得专利授权, 其余 41 项正在申报中, 学院专利数量位居重庆高职院 校前列。

\section{3 课程建设辐射多所高校}

学校与重庆市人力资源开发培训中心协同, 共同举办市级大学生创业 意识 (GYB) 培训, 由人力资源开发培训中信提供经费、教材和师资, 学校提 供场地、组织生源和培训管理, 已培训 4100 余人次, 拟在今年再培训 4000 余人次; 与重庆市大学生就业创业公共服务中心协同, 联合开展创新创业 导师团队建设、项目立项论证及服务、学生就业指导、人才测评、联合创 业等活动; 与重庆市沙坪坝区就业服务管理局与沙坪坝区科委等部门协同, 联合开展make block机器人培训。今年4月, 经培训的学生获得重庆市第十 二届高交会暨第八届国际军博会make block机器人大赛一等奖 2 人, 二等 奖 3 人。

3. 4 国内交流推广价值凸显
成果实施以来获得充分肯定,市政府、市教委等各级部门先后前来考 察近10次, 2016年5月被市教委遴选为重庆市“高校重创空间建设工作推进 会” 3所现场观摩及会场交流发言的高校之一。成为重庆市科委知识产权 标准化管理试点高校和重庆市 “双百示范行动” “众创空间” 建设授牌单 位。2015年以来已有近 10 余所高校前来专项考察学习, 具备良好的建设基 础, 具有良好的示范作用。《中国青年报》、《重庆日报》、重庆华龙网、网 易、搜狐等50余家全国主流媒体对学院创新创业教育成果进行近 60 篇专题 报道。

3. 5 创业典型引领就业质量提高

环境艺术系2016级环境艺术设计4班刘林金金、姜自强、谭晓渝同学等 组成创业团队, 入驻智造家众创空间, 主要负责室内设计以及室内施工图 制作, 从入驻以来, 共通过平台接到11项室内家装设计和 1 项工装设计, 截 止目前共完成8项家装设计, 还有 1 项工装设计正在制作当中, 截止目前刘 林金同学通过智造家平台共赚取设计费用约为 4 万余元, 其团队共产生直 接经济价值 32 万余元；2013级环境艺术设计系装饰艺术设计 2 班视觉传达 方向黄世沛同学, 2015年11月入住 “美好摄会” 众创空间项目负责人, 创建 了自己的团队, 主要从事摄影及摄像及设计服务, 先后接下校毕业生毕业 纪念册的拍摄任务、拉萨婚礼跟拍任务、系宣传册设计及印刷工作等, 累 计项目金额 4 万余元。

\section{[参考文献]}

[1]沈逸.高职穿心创业教育融入专业教育的再思考[J].宁波大学学报 (教育科学版),2016(3):55-56.

[2]占卫国.高职院校创新创业人才培养现状及对策研究[J].黄冈职业 技术学院学报,2016(1):10-11.

[3]强伟纲,战学秋.高职创新教育课程体系构建探析[J].职业技术教 育,2014(8):26-29.

作者简介：

潘越(1983--),女,汉族,四川南充, 副教授, 本科, 研究方向：数字媒 体技术。 